\title{
Keep up the momentum
}

\author{
The important gains in supporting local biomedical science made by South Africa's Medical Research Council in \\ recent years may be lost unless the country continues to fund and grow this important institution.
}

W ith the passing of Nelson Mandela in December of last year, the entire world paused to mourn South Africa's first post-apartheid president-and to reflect on how great leadership such as his can have a profoundly transformative effect. Good guidance is invaluable, and in this issue, a news feature by Linda Nordling (page 113) describes how the skilled leadership of Salim Abdool Karim has helped revitalize South Africa's Medical Research Council (MRC). Karim, who took up the role of MRC president in April 2012, is slated to step down next month. On his watch the national research and funding agency has grown its baseline grant budget from 246 million rand (R) (\$22 million) in the 2012-2013 fiscal year to R446 million in the 2014-2015 cycle. It's projected to grow to R648 million in 2016-2017.

Although these numbers are small when compared to funding giants such as the US National Institutes of Health (NIH), which was allocated an annual budget of $\$ 29.9$ billion in the budget approved by the US Government last month, the upward growth trajectory in South Africa is encouraging. The renaissance that the MRC has undergone comes at a time when the country badly needs biomedical breakthroughs: the World Health Organization reported almost 300,000 notifications of new cases of tuberculosis in South Africa in 2012 (http://www.who.int/tb/publications/global_report/gtbr13_ annex_2_country_profiles.pdf). According to estimates from that same year, about $12 \%$ of the people living there are infected with HIV (http://mg.co.za/article/2013-06-20-household-survey-hivprevalence-increases/). Even Mandela himself expressed regret for not having taken more aggressive action against the AIDS epidemic during his tenure as president. And the country is still fighting against the lingering AIDS denialism promoted under Mandela's successor, President Thabo Mbeki (Nat. Med. 12, 369, 2006).

Scientists who live in South Africa are best positioned to understand and address the country's local medical needs. They have enjoyed support from outside funders, such as the NIH and the Bill \& Melinda Gates Foundation, but the value of a local granting mechanism such as the MRC cannot be overstated. Unlike international funders, whose donations to South Africa are subject to pressures beyond the country's borders, the MRC, which was established in 1969, is accountable to the community to fulfill its self-stated mission to "improve the nation's health and quality of life through promoting and conducting relevant and responsive health research." It's for this reason that the MRC was described as a "national asset" by a panel commissioned by South Africa's Department of Arts, Culture, Science and Technology to review the institution in 1997. Indeed, the MRC funds a range of basic biomedical science and clinical research and public health studies. For example, the new funding has supported investigations into new therapeutic combinations for extensively drug-resistant tuberculosis at the University of Limpopo, which was a historically disadvantaged institution under apartheid, and 'Flagship' grants offered through the MRC have supported research such as studies on stem cells at the University of Pretoria.

Karim originally took on the leadership role at the MRC with the understanding that his tenure would be limited so that he could eventually return his full attention to leading the Centre for the AIDS Programme of Research in South Africa (CAPRISA). So it comes as no surprise that he will step down next month. As Nature Medicine went to press, a successor had not yet been named, and local scientists wonder whether the next MRC president will be able to convince the government to sustain its growing investment in science.

There is no excuse for South Africa to allow its financial support for the MRC to ebb in the future. The World Bank has forecast a growth rate of $2.7 \%$ in gross domestic product for South Africa in 2014 and a $3.4 \%$ growth rate for next year (http://www.bdlive. co.za/economy/2014/01/15/world-bank-upbeat-on-sa-growthprospects). Given this growth, the country should strengthen the MRC with investment beyond what is already committed, as local biomedical research can help propel the economy forward even further.

Under Karim's leadership, the MRC has not just grown-it has also reoriented its focus on supporting extramural research. Only about a quarter of the 2012-2013 MRC budget was spent on extramural grants, but these grants now account for about half of the latest budget. This redirection of money to extramural sites is essential if the MRC is to 'lift all boats' in the country with its research funding mandate. Thus, with its relatively strong infrastructure and its robust medical brainpower, South Africa can serve as a shining example for neighboring countries looking to build a framework for local research funding of academic medical centers and university labs. Karim and his team have acted as a spark plug to reignite the power of the MRC; it's now in the hands of the government and the institution's next leader to keep that powerful engine running. 